\author{
Mirosław Bogdan \\ Politechnika Opolska
}

\title{
Definicja piękna w XII wieku a architektoniczna ekspozycja ołtarza w epoce gotyckiej
}

Okres architektury gotyckiej rozpoczyna się wraz z rekonstrukcją bazyliki św. Dionizego w Saint-Denis na północy Paryża, ukończonej w pierwszej połowie XII wieku. To dziejowe wydarzenie bezpośrednio wpływające na definicję średniowiecznego piękna było związane z miejscem, które w tym okresie stało się sanktuarium narodowym i stolicą duchową Francji. Dokonało się to wraz z deklaracją królewską i dotyczyło relikwii Męki Pańskiej i św. Dionizego. Ich obecność, szczególnie po uroczystej konsekracji nowego chóru pierwszej bazyliki gotyckiej dokonanej z rozgłosem w dniu 11 czerwca 1144 roku, gromadziła cały lud Boży ${ }^{1}$.

Relikwie Męki Pańskiej, stanowiąc szczególne odzwierciedlenie dobra duchowego, stały się własnością opactwa w Saint-Denis za sprawą darowizny Karola II Łysego (823-877). Pięknie eksponowane, symbolizowały szczególną obecność piękna duchowego. Piękno to w odróżnieniu od cielesnego pozwala nam zrozumieć prawdziwe duchowe oblicze relikwii, które poprzez swoją ziemską obecność przywołują tą nieziemską, związaną z najwyższym dobrem i jego pięknem niewidzialnym dla naszych oczu.

Tę samą tajemnicę posiadały relikwie św. Dionizego, umieszczone w nowym gotyckim chórze. Były one szczególnie adorowane przez Ludwika VI

Zob. S. Melchior-Bonnet, Église et abbayes en France, Paris 1984, s. 12. 
(1080-1137), króla Francji od 1108 roku, który w momentach trudnych dla swojej ojczyzny, modlił się przed nimi w Saint-Denis.

Ludwik VI, trzymając w swojej dłoni chorągiew z Saint-Denis, zwyciężył dzięki wsparciu nieba, jak to podają pisma, przeciwników Francji i papiestwa ${ }^{2}$. Z punktu widzenia najwyższego dobra i piękna duchowego największym zwycięzcą jest św. Dionizy, a król pozostał jego lennikiem i w konsekwencji wasalem opactwa w Saint-Denis.

Począwszy od tych wydarzeń, wiara rosła i powstawały nowe legendy sprzyjające jej rozwojowi. Przy umocnieniu wiary równoległym torem rozwijała się historiografia dotycząca chwały św. Dionizego. Ten szacunek do relikwii, umacniający intuicyjny ogląd innej rzeczywistości, wpłynął na zdefiniowanie różnicy pomiędzy pięknem widzialnym cielesnym a niewidzialnym duchowym. Dotyczy to okresu przechodzenia z form romańskich na gotyckie, a co za tym idzie - nowego stanowiska estetycznego wobec oglądanej i tworzonej rzeczywistości. Duże znaczenie miały w XII wieku szkoły estetyczne, które - zainspirowane przemianami stylowymi w sztuce i architekturze - próbowały stworzyć nową definicję piękna.

\section{Opat Suger z Saint-Denis, twórca pierwszej świątyni gotyckiej, inspirującej poszukiwania definicji mistycznego, strukturalnego piękna}

Postać Sugera (1081-1151), opata w Saint-Denis od 1122 roku, przyjaciela Ludwika VI, pełniącego przy swoim królu funkcję pierwszego ministra, miała szczególne znaczenie przy odkrywaniu nowej średniowiecznej definicji piękna ${ }^{3}$.Zafascynowany witrażem, który w średniowieczu symbolizował obecność niewidzialnego piękna duchowego, zbudował nową świątynię na miejscu częściowo zachowanej romańskiej. Zastosowane w niej okna witrażowe stanowią ,wstęp” do przyszłych ogromnych ścian witrażowych, nigdy wcześniej niestosowanych, będących charakterystyczną cechą nowego wykreowanego tutaj stylu. Gotyckie ściany witrażowe w po-

Zob. O. von Simson, Katedra gotycka: jej narodziny i znaczenie, przeł. A. Palińska, Warszawa 1989, s. 104-106.

Zob. Les Cisterciens: Textes rédigés avec la collaboration de Julie Roux, Vic-en-Bigorre 1998, s. 117 . 
równaniu z romańskimi wpuszczały więcej światła do wnętrza świątyni. Gotyckie przeszklenia witrażowe są większe od romańskich witraży obejmowanych przez substancję ścienną muru, a dzięki strukturze maswerkowej mogą wypełniać cały obszar pomiędzy dwoma podtrzymującymi ich strukturę słupami zewnętrznymi budowli.

Ważne jest przy tym, że gdybyśmy w naszych czasach zastosowali w tym gotyckim systemie szkieletowym przeźroczyste szyby na miejscu kolorowych ścian witrażowych, wgląd do wnętrza sakralnego od zewnątrz byłby całkiem możliwy. Oczywiście w gotyku, zgodnie z zasadą wizualnego nieudostępniania wnętrza sacrum wobec profanum, konieczny był witraż. On sam pełnił rolę gotyckiej ściany osłonowej i zasłaniał - ale w duchu zbliżenia się do transparencji obcej romanizmowi - to, co ma pozostać tajemnicą wobec tego, co nią nie jest i pozostaje na zewnątrz.

„Refleksje nad przeświecaniem szkła, zainspirowane przez Sugera, opata z Saint-Denis, pozwalają nam zrozumieć całą cenę, jaką wkłada się wtenczas w witraże, i fascynacje, jaką one wywołują" ". Przy nowej realizacji odrestaurowano partie starego kościoła, które groziły zawaleniem. Dla realizowania swojej koncepcji opat Suger musiał znaleźć odpowiedni kamień i oczywiście zgromadzić drewno. Sprowadził również rzemieślników, artystów, kamieniarzy, złotników i przede wszystkim witrażystów5.

Opat Suger, będąc twórcą gotyku, zainicjował jednocześnie we Francji szkołę północną, do której obok Ile-de France przynależały Pikardia i Artois. Te trzy regiony stosowały przy realizacjach obecność dwóch symetrycznych wież fasadowych przewyższających strefę trzech portali wejściowych. Dopełnieniem tej kompozycji była rozeta zwana wielką różą i galeria królów stanowiących przodków Marii. Obok takiej zasady budowania frontonów elewacyjnych duże znaczenie ma częste zastosowanie we wnętrzu sklepień krzyżowych czterodzielnych i sześciodzielnych. Umacnia je konstrukcyjnie zastosowanie żeber a symbolicznie zastosowanie funkcji chórów otoczonych obejściem z kaplicami promienistymi. Nie zapomina się przy tym o akcentowaniu znaczenia planu bazylikowego, gdy jego dyspozycja została dostosowana do mistycznego odbioru tej rzeczywistości.

T. Castieau, L'art roman, Paris 1982, s. 57.

E. Panofsky, Architecture gothique et pensée scolastique précédé de L'abbé Suger de Saint-Denis, Alençon 1992, s. 61-64. 
Co ciekawe, że największy sukces Sugera dokonał się bez związku z wielkimi szkołami estetycznymi XII wieku. Ten wielki teolog i artysta, opierając swoje życie na modlitwie i umiłowaniu piękna, po prostu nakazywał budowniczym otworzyć (dzięki sklepieniom krzyżowym i żebrowym) chór na penetrację światła ${ }^{6}$. Tak zainicjowany gotyk, będący strukturalną symbiozą kamienia wapiennego i witraży, cechują trzy fazy rozwojowe. Są one prezentowane jako gotyk wczesny (1144-1200), gotyk promienisty (12001300) i płomienny (XIV wiek - początek XVI stulecia) ${ }^{7}$.

\section{Piękno w nauce św. Bernarda z Clairvaux}

jako baza poznania piękna moralnego i piękna czystego istnienia

Gotyk prezentowany w trzech fazach rozwojowych, odsłaniających różnice ekspresji architektonicznej wypowiedzi, wprowadził jednocześnie charakterystyczne urządzenie wnętrza świątyni. Dotyczy to szczególnego znaczenia gotyckiego ołtarza, który istniał wówczas we wnętrzu sakralnym jako ukryty wobec strefy nawowej, w chórze za lektorium.

Stanowiąc zachodnią elewację gotyckiego prezbiterium, lektorium manifestowało odziedziczoną funkcję klauzury zakonnika. Istniejąca na szczycie tej elewacji trybuna przewyższająca strefę trzech przęseł portyku z dwoma ołtarzami dla oficjantów kultu i symetrycznym wejściem z nawy do chóru pomiędzy nimi służyła głoszeniu tekstów wysławiających Pana. Diakon wchodził na nią schodami liturgicznymi i tam śpiewał po łacinie listy apostolskie oraz Ewangelię, a w monasterach z tego wysokiego miejsca czytane były nauki związane z nabożeństwem8.

Dostrzegając, że ukrywanie ołtarza liturgicznego za lektorium sprzyja odkrywaniu rzeczywistości piękna duchowego, tego ukrytego, należy nawiązać do nauki francuskiego teologa Hugona od Świętego Wiktora (1096-1141).

Ten paryski filozof przy pomocy koncepcji estetycznej swojego zakonu oddzielił piękno cielesne od tego duchowego. Te dwa gatunki piękna od-

6 Zob. M. Henry-Claude, L. Stefanon, Y. Zaballos, Principes et éléments de l'architecture religieuse médievale, Gavaudun 1997, s. 20.

Zob. W. Koch, Comment reconnaitre les styles en architecture, Gütersloh 1989, s. 26-30.

Zob. M. Bogdan, Prezbiterium w przestrzeni architektonicznej kościoła, Katowice 2008, s. 83. 
różniano już w starożytności, a w XII wieku wzmocniono ich niezależność. Proces ten dokonywał się przy akceptacji estetyki cystersów. Oczywiście była ona odmienna od estetyki Hugona od św. Wiktora. Dotyczy to wielkiego reprezentanta cystersów, św. Bernarda z Clairvaux (1090-1153).

Święty z Clairvaux akceptował całkowicie tylko piękno duchowe. Według niego wyraża ono obraz duszy i tylko taki duchowy jej obraz, istnieje w estetyce cystersów jako obowiązujący. Ważne, że sama nauka Kościoła uwzględnia ten fakt, istniejący w zgodzie z nierozdzielną triadą Platona (dobro, piękno, prawda), że możliwym jest, aby brzydka dusza zamieszkiwała w pięknym ciele i na odwrót.

Piękne ciało, piękna rzecz, piękny obraz mogą powodować konieczny poryw „poszukiwania" zasady, która rządzi wszechświatem. Ale sam w sobie ten zaczątek jest niczym, jeżeli nie postępuje za dochodzeniem do prawdy, dobra, piękna; form albo idei, które są źródłem, a jednocześnie przeznaczeniem całego obecnego świata. Z tych form niematerialnych, ponadziemskich nie można oddzielić piękna jako istoty autonomicznej, ani tym bardziej prawdy; to jest ich związek nierozerwalny, który jest dobrem najwyższym. Nie ma więc idei sztuki poza łonem tej triady.

Nie oznacza to bynajmniej, że piękno cielesne nie ma swojej aktywnej, oddziałującej duchowo egzystencji. Według cystersów jest ono tworzone z udziałem duszy, która próbuje promieniować poprzez ciało jak światło w ciemnościach. Jest to czynność przenikania przy pomocy promieni świetlnych bytu materialnego w celu jego przetworzenia. Dokonuje się tak aż do momentu, gdy przetwarzane ciało jest oglądane jako to, które przejęło blask. Wraz z odblaskiem duchowym to, co dotyczy działania, język wymowy, gesty, wszystko jest przyjmowane w przetworzeniu.

W tej egzystencji piękno moralne jest najważniejsze. Przy tym duchowość św. Bernarda z Clairvaux jest odmienna od dualizmu estetycznego starożytnych. Oni przeciwstawiali piękno duchowe temu cielesnemu. Tymczasem święty z Clairvaux rozpoczyna od rozumienia formy na tyle, na ile jest ona pewnym obrazem moralności. Pomimo tego taka koncepcja dotyka wrażliwie problemu etycznego w stosunku do jego aspektu estetycznego. „W piśmie św. Bernarda, polemizującym ze współczesną mu sztuką, zachowało się szczególnie powiedzenie o zdeformowanym pięknie,

9 A. Cauquelin, Les théories de l'art, Paris 1998, s. 18 (tłumaczenia pochodzą od autora artykułu). 
deformis formositas, i o pięknie deformacji, formosa deformitas. Jeśli formy zdeformowane są piękne, to dlatego, że są ekspresyjne. Słowa Bernarda są naturalnym odpowiednikiem sztuki romańskiej, która przedstawiając rzeczy realne, tak bardzo je deformowała"10.

Jest to zbliżone do poglądu, który wiąże piękno cielesne z duchowością, ale jako byt niższy hierarchicznie od niej. Duchowość przybliża się do rzeczywistości piękna, które dotyczy budowy duszy i które jako czyste istnienie nie istnieje źródłowo w świecie widzialnym. „Czyste istnienie jest bowiem pierwsze i ostatnie, wieczne i wciąż aktualnie obecne, najprostsze i największe, w najwyższym stopniu zaktualizowane i absolutnie niezmienne, najdoskonalsze i niezmierzone, w najwyższym stopniu jedno, a przecież wypełnione wszelkimi doskonałościami"11. Jest ono tworzone przez samego Boga i jest ono posadowione na najwyższym miejscu w systemie mistycznym. Oznacza to również, że nie jest możliwe, aby forma materialna kompozycji była porównywalna $\mathrm{z}$ tą, która jest tworzona dokładnie w sposób duchowy. Podążając za tą myślą, piękno cielesne jest klasyfikowane jako to "słabsze” od duchowości, podczas gdy ona powinna być wiązana egzystencjalnie z tym „silniejszym” pięknem.

Mówiąc inaczej, materialna rzeczywistość estetyczna powinna podążać za oczywistością estetyczną substancji wiecznej. Dotyczy to tak samo koncepcji teologicznej, która stwierdza, że nieśmiertelna dusza jest silniejsza od śmiertelnego ciała. Wraz z tą ideą, dotykającą problemu egzystencji tych podstawowych bytów, słusznym jest podkreślenie, że obydwa są traktowane zawsze nierozdzielnie w aspekcie ich stanu uczestnictwa w żywej obecności na ziemi.

\section{Piękno duchowe i cielesne w nauce cystersów jako baza poznania} piękna symbolicznego poszukiwanego przez Hugona od św. Wiktora

Egzystencjalizm dwóch podstawowych bytów, duszy i ciała, ulega utrwaleniu zgodnie z poglądem św. Bernarda, który pojmuje świat w dialogu ze

10 W. Tatarkiewicz, Historia estetyki, t. 2 Estetyka średniowiecza, Warszawa 1989, s. 139.

11 S. C. Napiórkowski, Św. Bonawentury „Droga duszy do Boga” [w:] Mistyka w życiu człowieka, pod red. W. Słomki, Lublin 1980, s. 152. 
swoją filozofią mistyczną, ewangeliczną i ascetyczną. Według niego człowiek został stworzony w celu oglądania prawdy. Oznaczało to jednocześnie, że powinnością takiego człowieka jest przejście długiej drogi. Święty z Clairvaux prezentuje cztery stopnie miłości i dwanaście stopni pokory. Wchodząc na tą drogę, stopień po stopniu, docieramy do szczytu, gdzie istnieje prawda. W tym systemie, który konstruuje stopnie w aspekcie mistycznym, występuje również piękno. Lecz św. Bernard nie rozpoznaje go u szczytu tej drabiny prowadzącej w prostej linii do nieba. Inaczej niż Hugon od św. Wiktora odnalazł je na niższym stopniu. Jest tak dlatego, że jest ono ukonstytuowane przez tego świętego od cystersów, jako piękno zmysłowe, cielesne i zewnętrzne ${ }^{12}$. Jako takie musi istnieć tylko na zasadzie uzupełnienia prawdy. Ona sama jest pięknem wiecznym, Boskim, całkowicie niedostrzegalnym w formie plastycznej ziemskiej. Wraz z tym odnajduje się rzeczywistość, która „kontroluje” obraz architektoniczny świątyni. Dzieje się tak również w okresie gotyckim.

\begin{abstract}
Cystersi ogałacali swe opactwa z rzeźb i z obrazów, które ozdabiały kościoły romańskie, aby zostawić miejsce kamieniowi gładkiemu, nagiemu, o kolorze pustyni. Preferowali linie proste, płytkie wezgłowia o formach zakrzywionych absyd. Chodzi o to, aby z prostoty ich budowli, rozważnie oczyszczanej z wszystkich ubogaceń czy też z rygoru tej architektury tworzonej dla trwania, wytrysnęła jasność poprzez czystość tych linii. Tak jest, gdyż życie zakonnika jest również poszukiwaniem, poprzez pojętność i inteligencję świętego tekstu. Cystersi lubili określać swe kościoły jako oratoria. Przeznaczone jedynie na użytek wspólnoty nie zawierają ani empor, ani trybun. Ich wymiary początkowo były zdecydowanie bardziej skromne od kościołów kluniackich, nawet jeżeli od połowy XII wieku kościoły cysterskie, które osłaniają wspólnoty coraz to liczniejsze, powiększały się skutecznie i jeżeli na małym sanktuarium o płytkim wezgłowiu dopiero co ukonstytuowało się sanktuarium obszerniejsze, z obejściem i kaplicami promienistymi ${ }^{13}$.
\end{abstract}

Dotyczy to architektury, która przekonuje o istnieniu piękna całkowicie matematycznego. Poglądy św. Augustyna nie są obce tej koncepcji. Odnosi się to także do jego kanoników regularnych, odpowiedzialnych za wprowadzenie reformy gregoriańskiej. „Ci klerycy, często nazywani kanonikami św. Augustyna, tak jak benedyktyni, poprzez przestrzeganie własnych ślubów i praktykę medytacji oraz modlitwę, tworzyli dla siebie walory mona-

12 Zob. W. Tatarkiewicz, Historia estetyki, dz. cyt., s. 168-169.

13 Les Cisterciens, dz. cyt., s. 54-55. 
styczne. Wyrzekali się głównie całego dobra osobistego, a był to element, do którego Augustyn przywiązywał szczególne znaczenie"14.

Są to reguły duchowe i ascetyczne, aktualne również dzisiaj. W konsekwencji chodzi o architekturę tworzącą formy naturalnie potrzebne, nie służące splendorowi i chwale ludzkiej, gdzie doskonała proporcja, nazywana tak z powodu przejrzystości konstrukcyjno-funkcjonalnej, istnieje jako ta użytkowo niezbędna ${ }^{15}$.

Według tej metody konstruuje się dom Boży, którego harmonia jest budowana na module liczbowym. To uzasadnienie zastosowania Wielkiej Teorii Piękna stworzonej przez starożytnych Greków, opiera się przede wszystkim na metafizyce „świętej prostoty”, która transcendentnie się udzielając, tworzy i wznosi budowlę świątyni, której piękno jest porównywalne z tym z kosmosu i tym muzyki. Proporcja geometryczna przynosi zawsze $\mathrm{w}$ takim miejscu dobre rozwiązanie problemu plastycznego. Stosuje się to konsekwentnie w formie tworzonej bez udziału dekoracji. Taką formę organizuje się jako tę przyporządkowaną funkcji odtwarzania piękna niewidzialnego, niebiańskiego, absolutnie doskonałego.

Mistyk i teolog Hugon od Świętego Wiktora (1096-1141) ma ogromny udział w określaniu zakresu egzystencji piękna niewidzialnego. Jednakże w tym samym czasie dla niego, który jest estetykiem, to niewidzialne jest podobne do widzialnego, a ono samo w sobie wywołuje zachwyt (admiratio) i przyjemność (delectatio). Przy tym jest możliwe, aby takie piękno istniało dla niego samego. Wszystko to dotyczy piękna zrozumiałego przez zmysły i wyobraźnię (imaginatio).

„Metafizyczne zaś piękno posiada tylko swe podstawy w elementach rzeczy, a formalnie jest metafizycznym pięknem przez całościowe związanie bytu z porządkiem intencjonalnym, a więc z poznawczą wizją i budzącym się w niej pierwszym aktem miłości"16. Jest ono odmienne od tego widzialnego i jest traktowane przez zakon św. Wiktora jako rzeczywistość pojmowana przy pomocy inteligencji (intelligentia). Gdy ona sama poprzez swoją myśl intuicyjną jest wykorzystywana przy kontemplacji tego najwyższego piękna, ono jako to najwyższe i niewidzial-

14 Tamże, S. 31.

15 Zob. A. Erlande-Brandenburg, De pierre, d'or et de feu, Fayard 1999, s. 154-155.

16 M. A. Krąpiec OP, Metafizyka, Lublin 1985, s. 215. 
ne dla oczu ziemskich jest pięknem prostym (simplex et uniformis). Przy nim to, co widzialne, jest definiowane jako złożone i niejednolite (multiplex et varia proportione conducta). Pomimo odmienności te dwa gatunki piękna nie są absolutnie rozdzielone, a piękno widzialne oznacza to, co niewidzialne i je wyraża ${ }^{17}$.

Ta współzależność estetyczna dotyka problemu symbolizmu metafizycznego. Jest to wytłumaczone przez Hugona od św. Wiktora, który posiada swoją specyficzną interpretację tej kwestii.

Dla tego mistyka z XII wieku świat się jawi quasi quidam liber scriptis digito Dei, trochę jak książka redagowana za pomocą palca bożego (De tribus diebus, PL 176, coll. 814), a uwrażliwienie na piękno własne w stworzeniu ludzkim jest ukierunkowane głównie ku odkryciu piękna zrozumiałego. Uczucia radosne zrodzone ze wzroku, słuchu, zapachu, dotyku, otwierają nas na piękno wszechświata tylko po to aby móc w nim odkryć Boże odbicie ${ }^{18}$.

Oznacza to, że piękno widzialne jest odnajdywane przez Hugona jako to, które jest znakiem (signum) i obrazem (imago) niewidzialnego. Pragnie, aby stało się rozpoznawalne w sensie postaciowym (figuratywnym) i symbolicznie (symbolice) ${ }^{19}$. Wszystko to odnosi się do piękna prawdziwego, boskiego w swoim wiecznym charakterze. Mistyk od św. Wiktora jest konsekwentny w tym, co jest uwielbieniem harmonii niebiańskiej. Wyraża ona piękno samego Boga i każda inna harmonia jest odmienna od niego. Jest to admiracja Nieśmiertelnego, który posiada swój dom, zbudowany również według tego samego sposobu. Mówiąc inaczej, nieśmiertelność jest tym elementem, który wiąże Boga ze swoim mieszkaniem. Wszystko to dotyczy piękna niewidzialnego, niedostępnego dla naszych oczu. Przy tym jednak możliwym jest jego odnalezienie w naszym świecie.

Wszystkie obiekty widzialne są nam oferowane w sposób widzialny, aby rozbudzić nasz zmysł symboliczny. Oznacza to, że są one nam proponowane poprzez ich przetworzenie odtwarzające kontekst znaczenia i deklaracji obiektów widzialnych. Tak więc w efekcie piękno obiektów widzialnych przebywa w ich aspektach formalnych, [...] a piękno dostrzegalne jest obrazem piękna niedostrzegalnego ${ }^{20}$.

\footnotetext{
17 Zob. W. Tatarkiewicz, Historia estetyki, dz. cyt., s. 174.

18 U. Eco, Art et beauté dans l'esthétique médiévale, Paris 1997, s. 105-106.

19 W. Tatarkiewicz, Historia estetyki, dz. cyt., s. 178.

$20 \quad$ U. Eco, Art et beauté..., dz. cyt., s. 106.
} 


\title{
Humanistyczna estetyka mistycznej szkoły w Chartres a umocnienie pozycji piękna cielesnego oddzielonego od piękna duchowego w nauce Hugona od św. Wiktora
}

W kwestii definiowania piękna dostrzegalnego jako tego będącego obrazem niedostrzegalnego przedstawiła swoją interpretację filozoficzną szkoła z Chartres. Jest ona tą trzecią z XII wieku, która - obok szkoły estetycznej cystersów z Clairvaux i zakonu paryskiego św. Wiktora - wniosła niezbędną naukę w kontekście odnajdywania piękna niewidzialnego w świecie widzialnym. Jej reprezentanci, powołujący się na rzadkie, nieznane rękopisy i przekłady naukowych dzieł starożytnych, byli humanistami akceptującymi wyraźnie platońskie założenia. Dlatego Arystoteles, uczeń, nauczyciel i badacz Akademii Platońskiej, wraz ze swoją umiarkowaną empiryczną teorią poznania stał się wyraźnie ich natchnieniem ${ }^{21}$.

\begin{abstract}
Z Platona można czerpać różne estetyki: idealistyczną, mówiącą, że prawdziwie piękna jest tylko idea i spirytualistyczną, mówiącą, że prawdziwie piękny jest tylko duch. Chartryjscy uczeni wzięli od niego jeszcze inną: matematyczną, o naczelnej tezie, że prawdziwie piękna jest tylko proporcja. Estetyka ta, którą w średniowieczu wprowadzili Augustyn i Boecjusz, była właściwie pitagorejska, ale przez Platona przejęta. W jego dialogu Timajos uczeni XII wieku znaleźli myśl, że świat jest przez Stwórcę zbudowany matematycznie, że prawem stworzenia jest prawo proporcji ${ }^{22}$.
\end{abstract}

Jest to czytelnie ukazane w architekturze gotyckiej, która realizuje program estetyczny tej humanistyczno-mistycznej szkoły. Chodzi o intencję artystyczną, która przetwarza system techniczny konstrukcji w strukturę plastyczną. Odnośnie do tej koncepcji katedra z Chartres, która jest manifestacją proporcji liczbowych, dokonuje tego przy pomocy aspektu ekspozycji formalnej. Według historyków architektury wszystkie szczegóły formalne tej katedry były realizowane jako wynik obliczenia i ani jeden nie powstał dla samej tylko ozdoby.

„Architektura średniowieczna wprawdzie od początku posługiwała się geometrią, ale początkowo z intencją raczej techniczną, a dopiero od go-

${ }^{21}$ Zob. W. Tatarkiewicz: Historia filozofii, t. 1 Filozofia starożytna i średniowieczna, Warszawa 1983, s. 239.

22 Tenże, Historia estetyki, dz. cyt., s. 185-186. 
tyku wyraźnie estetyczną"23. Tak więc piękno proporcji jest nieodzowne w okresie pierwszej połowy XII wieku. Tak samo wraz z platonizmem odkrywany jest kult matematyki: zauważono jej świat jako ten, który się utrwala, współegzystując w zgodzie z prawami natury. Jeżeli istnieje ta zgodność, oznacza to, że chodzi o formę gotycką, gdzie geometria jest przedłużeniem stworzenia, którego natura jest kreowana bezpośrednio przez Boga ${ }^{24}$. Przy pomocy takiej formy geometrycznej możliwe jest realizowanie tego wiecznego piękna odnajdywanego w świecie.

Dla szkoły w Chartres kosmos będzie faktycznie dziełem Boga, a ład całości, który zastępuje chaos pierwotny, będzie ładem boskim. W jednym takim działaniu rola pośredniczki będzie przypadać Naturze, sile nierozłącznie związanej z rzeczami, która to produkuje, począwszy od rzeczy podobnych, inne rzeczy podobne (vis quaedam rebus insita, similia de similibus operans) $i$ tak jest powiedziane w Dragmaticon (I) Guillaume'a z Conches. Według optyki metafizyki Chartrystów natura nie redukuje się do personifikacji alegorycznej, objawi się ona wyraźnie raczej jako rdzeń, siła, od której zależy narodzenie i wzrost rzeczy ${ }^{25}$.

W tym samym czasie Hugon od św. Wiktora nie odnajduje w kosmosie tylko dzieła Bożego. To, że Bóg jest największym twórcą, jest oczywiste dla tego filozofa.

Grupuje on dzieła w trzech kategoriach; te Boże, odkrywane w stworzeniu, te z natury, które aktualizują stworzenie Boskie, te od człowieka, który je przekształca, naśladując naturę. Postawienie na przyczynę podziału pomiędzy trivium a quadrivium staje się nośnikiem przyszłości. Hugon od Świętego Wiktora rozwodzi się nad jakościami ludzkiej twórczości, precyzującje w słowach: qualitas, color, formatio, compositio. Nie ustala on w zasadzie różnicy, jak to się robi dzisiaj, pomiędzy dziełami sztuki a produktami nieodzownymi dla człowieka, jego życia, jego potrzeb, tym, co nazywa on sztukami mechanicznymi, odpowiedzialnymi za ułatwianie życia, tak jak ubrania ${ }^{26}$.

Tymczasem problem samodzielności form rzeczy i obiektów, które to formy mogłyby zaistnieć dla nich samych, jest następnym aspektem dotyczącym kosmosu i jego natury. Możliwe jest przy tym, aby natura stała się podziwiana z pomocą tych, którzy ją oglądają, i dotyczy to problemu, jak

\footnotetext{
$23 \quad$ Tamże, s. 186.

24 Zob. O. von Simson, Katedra gotycka, dz. cyt., s. 53.

25 U. Eco, Art et beauté..., dz. cyt., s. 62-63.

26 A. Erlande-Brandenburg, De pierre, d'or et de feu, dz. cyt., s. 207-208.
} 
ją kreować dla jej własnego piękna. Tutaj rozmaitość form komunikatywnego oddziaływania przywołuje taką kwestię definitywnie. Są to na przykład wielkości rzeczy, które przy pomocy ich różnorodności konstytuują zmienny obraz estetyczny. To, co jest wielkie, jest oglądane i podziwiane inaczej od tego, co jest małe. To samo dotyczy świata kolorów i form. Wraz z rzeczami, które są odmienne, piękno istnieje w aspekcie różnorodności. Również dlatego takie rzeczy są godne podziwu. Utrzymują one swój byt tak jakby poprzez ich bogactwo form, kolorów, rozmiarów, zapachów i dźwięków.

Piękno widzialne ma w tych bytach swój widoczny udział. Hugon od św. Wiktora zajmuje się tym problemem w sposób szczególny. Według niego natura jest piękna również dla niej samej. Chodzi o koncepcję (jedyną w średniowieczu), według której definicja formy w jej aspekcie estetycznym poszerza sferę swojej autonomii. Wraz z tym, pozycja piękna widzialnego jest wyraźnie umocniona. Podobna koncepcja jest konieczna, ażeby nasz świat zaistniał jako piękny, gdy jest oglądany.

Hugon od św. Wiktora stwierdza, że w istocie piękno widzialne jest obrazem (imago) i znakiem (signum) tego niewidzialnego, określanego jako boskie i prawdziwe. Odnośnie do tego stwierdzenia jego autor odnajduje nowe uwarunkowania w sferze estetycznej. Próbuje powiedzieć, że każde piękno jest cenne samo przez się. W tym miejscu język wymowy symbolicznej nie zawsze jest konieczny i filozof od św. Wiktora zaczyna podziwiać świat zbudowany przy obecności zasad uwzględniających cielesność naszej egzystencji. Wobec tego faktu możliwym jest, że piękno będzie zawarte we wszystkich darach zmysłowych. Przy takiej obserwacji natury objawia się odnowa estetyczna, która oddziela piękno widzialne od tego niewidzialnego. Hugon jako pierwszy akceptuje tę koncepcję i eksponuje ją w zgodzie z ideami swojego zakonu.

Te dwa gatunki piękna umacniają się wraz z procesem rozdzielenia. Wszystko to jest odpowiedzialne za ład, który istnieje w tym celu, aby natura stała się uporządkowaną i eksponowaną widzialnie oraz niewidzialnie. Oznacza to, że oddzielenie piękna cielesnego od tego duchowego konstruuje niezbędny most pomiędzy nimi. Ten most to, inaczej mówiąc, możliwość oglądania niewidzialnego jako tego widzialnego. Dotyczy ona w dużej części liturgii, która staje się ponad wszystko wypowiedzią bardzo bliską estetyce. 
Po pierwsze dotyka to problemu możliwości prawidłowego odczytu podwójnej obecności Chrystusa, który w trakcie przeistoczenia liturgicznego, będąc kapłanem, staje się jednocześnie ofiarąa ${ }^{27}$. Po drugie dotyczy to oglądalności cielesnej tak samo jak tej duchowej, objawiającej intelektowi w sposób jednoznaczny, przy pomocy tej pierwszej, realne postaciowo „ukrywanie się" rzeczywistości osobowej Chrystusa, co jest realizowane w obszarze niewidzialnej Komunii przy trwaniu w łasce uświęcającej ${ }^{28}$.

Dwie powyższe oglądalności albo percepcje są związane z dwoma odpowiednimi gatunkami piękna, które były wykorzystane w gotyku przy budowie sacrum. Oznacza to, że obecność piękna cielesnego i tego duchowego była pomocą przy konstruowaniu ołtarza w tamtej epoce.

\section{Piękno duchowe i cielesne ołtarza zamkniętego w architektonicznej przestrzeni gotyckiego chóru}

Problem oddzielenia piękna duchowego od cielesnego jest dostrzegalny w gotyku, gdy stół ofiarny jest budowany jako obiekt niewidzialny dla wiernych świeckich zgromadzonych w strefie nawowej. Tak też, w obliczu wspomnianego estetycznego aspektu oglądalności cielesnej i duchowej, myśl Hugona od św. Wiktora jest do zrealizowania tylko wobec wydzielonej we wnętrzu sakralnym wspólnoty kleru. Dotyczy to gotyckiego chóru, wnętrza odseparowanego po jego stronie zachodniej przez lektorium od reszty przestrzeni orientowanego kościoła. Tak ukryty ołtarz jest dostrzegany symbolicznie jako źródło piękna niewidzialnego. Jako taki powinien być tutaj adorowany i tak się dzieje, gdy przy jego zamknięciu podkreśla się symbolicznie rzeczywistość jego liturgicznej anamnezy i czuwania w obrazie niewidzialnego centrum.

$\mathrm{Z}$ reguły w gotyku takie zamknięte dla świeckich centrum eucharystyczne jest odpowiednie przy architektonicznej realizacji w przestrzeni sakralnej. Chodzi o zamknięcie wydzielonej przestrzeni na wschodnim zakończeniu osi architektonicznej, przy średniowiecznym oddźwięku mona-

${ }_{27}$ Zob. A. Bandelier, Simples questions sur la Messe et la liturgie, Chambray-lès-Tours 1999, s. $12-13$.

28 Zob. Jan Paweł II, enc. Ecclesia de Eucharistia, 36. 
stycznym, poprawnym dla zachowania majestatu ołtarza oglądanego tylko przez kler we wnętrzu gotyckiego chóru. Tam na jego zakończeniu jest umiejscowiony ołtarz, a miejsce jego umiejscowienia wydziela strefę nazywaną sanktuarium.

Dotyczy to gotyckiego ołtarza „kurtynowego”, czyli tego otoczonego od północy, wschodu i południa przez kurtyny, których kolor odpowiada okresowi liturgicznemu w Kościele ${ }^{29}$. Oczywiście strona zachodnia bezpośredniego otoczenia takiego blokowego ołtarza nie posiadała zasłony i pozwalała podejść celebransowi do mensy, aby dokonać na niej przeistoczenia chleba i wina w ciało i krew Pańską. Gdy dokonywał on tego odwrócony plecami wobec strefy kleryków zgromadzonych w stallach poprzedzających osiowo sanktuarium i flankujących dwustronnie poprzez ich równoległe rzędy główną oś układu chóru, to, co działo się na ołtarzu, pozostawało wówczas w ukryciu. Decydowała o tym nie tylko postać zasłaniającego mensę, ale również rzędy stalli, które zapewniają bezpośrednie zwrócenie się kleryków w nich zasiadających i klęczących względem siebie, a nie w stronę ołtarza. Miało to szczególne znaczenie przy długich chórach gotyckich, których sanktuarium poprzedzone długą strefą rzędów stalli stawało się odległym elementem wobec lektorium rozpoczynającego cały ten układ.

Podkreślmy, że jako następstwo realizowanej od końca XVI wieku trydentynizacji kościołów udokumentowanej przez sobór trydencki (15451563), nakazującej wyburzanie gotyckich lektoriów i niebudowanie nowych, niektóre z nich znikają nawet jeszcze w XVIII i XIX stuleciu ${ }^{30}$. Dotyczy to historycznego przedłużenia udziału w mistycznym dziedzictwie gotyckim, które odseparowywało ołtarz, symbolizujący źródło świętości i piękna duchowego, od strefy naw. Mimo obecności innych stołów ofiarnych we wnętrzu trójnawowym (albo jeszcze większym) ołtarz ukryty za lektorium, właśnie poprzez jego ukrycie, stawał się wówczas najważniejszym stołem ofiarnym.

Tak się działo z ołtarzem głównym noszącym miano historycznego, który był odsunięty od muru kościelnego, zbudowanego często w formie absydy. Historyczny ołtarz posiadał grób poniżej swojej mensy, umiejscawiany tutaj obowiązkowo aż do czasów Vaticanum II na początku drugiej

${ }_{29}$ Zob. B. Chedozeau, Choeur clos, choeur ouvert, Paris 1998, s. 64-65

30 Zob. tamże, s. 90-91. 
połowy XX stulecia. Ta metoda przechowywania świętych relikwii dzisiaj nie jest konieczna, podobnie jak i predella budowana jako niski naczółek na mensie, począwszy od późnego średniowiecza aż do czasów poprzedzających II Sobór Watykański.

Wspomniany naczółek w późnym gotyku, czyli po okresie ołtarzy kurtynowych, stanowił podstawę dla ogromnego retabulum, mającego płaszczyznę centralnego pola dogodnego dla ekspozycji obrazowej, przewyższonego wysokim zwieńczeniem ${ }^{31}$. Gdy retabulum jeszcze nie istniało, niekiedy odnajdywano tło predelli jako odpowiednie dla umieszczenia za nią, a co najważniejsze - ponad nią puszki eucharystycznej ze świętymi postaciami (hostiami) albo relikwiarza.

Umieszczenie relikwiarza nad gotyckim stołem ofiarnym dotyczy przede wszystkim ołtarzy w kaplicach promienistych, a prekursorem tego był opat Suger z Saint-Denis. Wedle jego decyzji właśnie w tym miejscu umieszczano relikwie świętych po ich przeniesieniu z krypty. W konsekwencji, relikwie nad ołtarzem, eksponowane w odpowiednim relikwiarzu, miały być według zamysłu opata przeświecane przez światło tak jak witraż. „Teologia ta opiera się na idei, że światło jest boską manifestacją, a raczej na tym, że «Bóg jest światłością» i że każdy byt otrzymuje i przekazuje to światło według hierarchii znanej Bogu" ${ }^{\prime 2}$.

Jeżeli Hugon od św. Wiktora pojmował już piękno bytów jako rzecz zależną od położenia przestrzennego (situs) i od ruchu (motus), a nie tylko od wyglądu (species) oraz jakości (qualitas), to wszystkie te kategorie są obecne w każdej epoce i są one potrzebne, aby odnaleźć piękno, które dotyczy Eucharystii, a także formy budowanej w jej strefie. Jest oczywistym, że poruszanie się księdza przy ołtarzu decyduje w jakimś stopniu o formie stołu ofiarnego. Podobna współegzystencja odpowiedzialna za estetykę istnieje w całej przestrzeni sakralnej kościoła. Oznacza to, że piękno niewidzialne poniekąd szuka tego widzialnego i na odwrót. Mówiąc inaczej, symboliczne środki wyrazu dotykają problemu kompozycji plastycznej i to, co pozostaje w następstwie tej transfiguracji, jest formą, która mogłaby istnieć jako ta autentyczna.

31 Zob. J. Danilewicz, Kościół i jego wnętrze, Kielce 1948, s. 98.

32 Zob. M. Henry-Claude, L. Stefanon et Y. Zaballos, Principe et éléments de l'architecture religieuse médievale, dz. cyt., s. 20. 


\section{Piękno duchowe i cielesne a strukturalna i funkcjonalna przestrzeń otoczenia ołtarza}

Dla identyfikacji formalnej, która przybliża symbolicznie niebo do ziemi, ołtarz w przestrzeni sacrum w czasie ojców Kościoła (epoka antyczna) był ustawiany tak jak prosty stół ofiarny, w obrazie niczym nienadbudowywanej mensy usadowionej na bazie jednoznacznie eksponującej tylko swoją funkcję podpierania. Święte postacie, podobnie jak w epoce gotyckiej, nie były wcześniej eksponowane na mensie, ale w innym miejscu kościoła, a nawet w zakrystii, jako rzeczywistość bardziej ukryta dla oczu wiernego przebywającego w nawie świątyni ${ }^{33}$.

Dotyczy to naszego Pana, który jakby w ukryciu pozostawił swoje ciało i swoją krew jako świętą Komunię, gdzie każdy poprzez służbę kapłańską może odnaleźć pokarm wieczny ${ }^{34}$. Tak też, wraz z pochodzącym jeszcze z epoki ojców Kościoła odsunięciem świętych postaci od ołtarza, istnieje pierwszoplanowość „świętego znaku” akcji liturgicznej bez elementu przechowywania Komunii Świętej i wszystko rozpoczyna się i kończy na mensie stołu ofiarnego. Wraz z podstawą - stipes - tworzy ona podstawową definicję zawsze aktualnej dwuczęściowej budowy ołtarza, który jest miejscem wybornie przystosowanym, aby złożyć świętą ofiarę ${ }^{35}$.

Wraz z historycznym oddzieleniem miejsca przechowywania Komunii Świętej względem ołtarza umocniła się funkcja oddzielenia piękna cielesnego od tego duchowego. Wraz z tym możliwe było, a dotyczy to na pewno gotyku, aby cała przestrzeń kościoła była oglądana w kontekście tajemnicy mistycznej, a nie ekspozycji czysto scenograficznej. Tymczasem aspekt scenograficzny wiąże się na pewno z kwestią ekspozycji krzyża i świeczników, które w trakcie celebry nie mogły się znajdować na mensie gotyckiego ołtarza. Najważniejsze jest jednak to, że umieszczenie wspomnianych rekwizytów na mensie ołtarzowej w czasie gdy nie była ona wykorzystywana do obrzędu liturgicznego, przypomina o symbolice, jaką one prezentują.

33 Zob. M. Bogdan, Architektura formy historycznej kościoła a ołtarz współczesny - Architecture de la forme historique de l'église et l'autel contemporain, Katowice 2003, s. 45 i 46.

34 Zob. Ogólne wprowadzenie do Mszału rzymskiego (edycja 1975), nr 285 i 292. Kodeks prawa kanonicznego (edycja 1983), kan. 939.

35 Zob. M. Bogdan, Architektura formy historycznej..., dz. cyt., s. 42. 
Krzyż jest umiejscowiony na ołtarzu pomiędzy dwoma świecznikami, ponieważ Jezus Chrystus przebywa w Kościele jako pośrednik pomiędzy dwoma narodami. Jest On kamieniem węgielnym, który w miejscu dwóch murów ustanawia ten jeden. Ku niemu przybyli pasterze z Judei i Mędrcy ze wschodu ${ }^{36}$.

Jest to proces tworzenia, w którym wszystko rozpoczyna się od kompozycji w centrum Domu Bożego. To znaczy w ołtarzu, który staje się źródłem kompozycji wnętrza tak samo jak obrysu zewnętrznego obiektu świątyni.

Zgodnie z tradycyjnym zwyczajem Kościoła i ze względu na znaczenie symboliczne, mensa ołtarza stałego winna być kamienna, i to z kamienia naturalnego. Za zgodą Konferencji Episkopatu można użyć innego materiału wartościowego, trwałego i odpowiednio obrobionego. Fundament i podstawa podtrzymujące mensę ołtarza mogą być z dowolnego materiału, byleby godnego i trwałego ${ }^{37}$.

Istnieje w tym miejscu obecność piękna widzialnego i niewidzialnego. Te dwa gatunki piękna są tutaj traktowane rozdzielnie przy pomocy definicji, która podkreśla, że każdy obiekt formalny posiada swoje otoczenie, przede wszystkim przez nas oglądane. Oczywiście to ostatnie jest nieodzowne, aby zdefiniować obiekt przynależący do niego.

Poprzez gotyckie traktowanie otoczenia jako przestrzeni przezroczystej i nieobecności języka plastycznego ornamentu wielu detali stan przebywania człowieka w takim architektonicznym środowisku staje się czytelną oczywistością, przywołującą element racjonalnego kontrastu. „Rzeczy materialne znajdują się tylko w tym miejscu, nie są obecne. Lecz osoby ludzkie poprzez ich ciało udzielają się sobie nawzajem poprzez ich obecność"38.

Przy uwzględnieniu tego aspektu funkcja obiektu przejmuje swoją nową misję. Dotyczy to stosowności estetycznej, gdy dotyka ona przestrzeni piękna niewidzialnego i zaczyna trwać, istniejąc razem z nim w stanie współzależności. Teraz przestrzeń przezroczysta jest konieczna, aby określić obiekt, który ona otacza. Mówiąc jeszcze inaczej, racjonalny kontrast formalny i nie tylko taki jest konieczny w celu odnalezienia piękna jako dwóch rzeczywistości, tej widzialnej i tej niewidzialnej, egzystujących oddzielnie.

36 P. Saurat, Le crucifix dans l'art, Paris 2001, s. 82.

37 To czyńcie na moją pamiątkę, Eucharystia w dokumentach Kościoła, oprac. J. Miazek, Warszawa 1987, s. 138

38 A. Bandelier, Simples questions sur la Messe et la liturgie, dz. cyt., s. 21. 
Jest to również kwestia ołtarza, który jest poniekąd źródłem akcji dynamicznej. Chodzi o aktywność symbolicznego i funkcjonalnego gestu rąk księdza na mensie stołu ofiarnego i powyżej niej w trakcie sprawowania liturgii.

Koncepcja Hugona z czasów średniowiecznych, według której piękno jest kwestią usytuowania przestrzennego, ruchu, wyglądu i jakości, jest akceptowana w każdej epoce. Dokonuje się to oczywiście wraz z historycznym oddzieleniem piękna cielesnego od tego niewidzialnego. Istnieje również liturgia święta, która formuje most nie tylko duchowy pomiędzy tymi dwoma autonomicznymi rzeczywistościami. Dzisiaj jest ona dostępna wizualnie dla każdej osoby, która znajduje się w nawie kościoła. Teraz wszystkie elementy wnętrza są oglądane dla nich samych. Przy tym wypełniają one tylko swoją podstawową funkcję. To znaczy, że istnieją wyraźnie w aspekcie służby, kiedy rozgrywają się liturgia Eucharystii i liturgia słowa. Autonomia obiektów jest tutaj rzeczywistością, która podkreśla obecność piękna odpowiedniości (funkcjonalności) jako tego wystarczającego.

Prekursorem wystarczalności piękna odpowiedniości w gotyku był opat Suger. Wznosząc pierwszy chór gotycki w Saint-Denis, zaproponował, aby przy jego mniejszej długości w porównaniu z katedrami nie uwzględniano lektorium ${ }^{39}$.

Poprzez indywidualizm strukturalno-użytkowy odnajdywany w każdym obiekcie, który spełnia swoją funkcję liturgiczną, umacniana jest jednocześnie pozycja piękna cielesnego. To niewidzialne pozostaje jak zawsze niewidzialne, ponieważ takie jest jego przeznaczenie. Przy autonomii obiektów liturgicznych dostrzegalny jest ruch i to wszystko, co się naokoło nich dzieje. Mówiąc inaczej, przestrzeń pomiędzy nimi, wraz z obecnością osób przebywających głównie tutaj w określonej pozycji modlitewnej (klęczącej, stojącej, siedzącej), jest czymś, co ułatwia funkcjonalne i symboliczne samodefiniowanie się tych obiektów.

Indywidualizm formy funkcjonalnej związany jest w tym wypadku z estetyką przestrzeni przeświecającej, która definiuje wszystkie obiekty nieprzeźroczyste umiejscowione wewnątrz niej samej. Dotyczy to również

${ }^{39}$ Zob. O. Czerner, Chór kapłański i lektorium NMP we Wrocławiu w XIV wieku. Podstawy rekonstrukcji i zwiazane z tym problemy, „Kwartalnik Architektury i Urbanistyki” 1965, zeszyt 3-4, s. 203. 
problemu kontrastu. Jest on tutaj realizowany na bazie kompozycji, gdzie linie wertykalne stają się plastycznym dopełnieniem tych horyzontalnych.

Jeśli podążamy za linią horyzontalną, zauważamy, że wyraża sens immanentności, racjonalizmu, intelektualizmu. Jest równoległa do ziemi, po której chodzi człowiek, towarzyszy jego przemieszczaniu się. Linia ta rozwija się w jednakowej odległości od oka. Trzymając się swojego toru, spotyka zawsze przeszkodę, która podkreślajej ograniczenie.

Linia wertykalna jest symbolem nieskończoności, ekstazy, emocji. Człowiek, aby podążać za nią, zatrzymuje się, odrywając się od normalnego kierunku, wznosi wzrok aż do nieba. Linia wertykalna kończy się w niebie, zanurza się w nim, nie spotyka ani przeszkód, ani ograniczeń. Jest symbolem wzniosłości ${ }^{40}$.

Odnajdujemy to szczególnie w wertykalnej architekturze gotyckiej wraz z zastosowaniem horyzontalnego układu trybuny lektorium. Taka pozioma przegroda wyraża przy swojej odmienności formalnej w stosunku do strzelistości gotyckiej obecność piękna cielesnego. To właśnie ono przy pomocy poziomej bariery lektorium decyduje o funkcji widzialności we wnętrzu kościoła. Kiedy istnieją jednak drzwi wejściowe w centrum lektorium, prowadzące z nawy centralnej do chóru, oznacza to, że istnieje również piękno duchowe, odmienne od tego widzialnego, przebywające w ukryciu. Jest ono odpowiedzialne za ołtarz eucharystyczny, który gdy pozostaje ukrywany, wyraża fragment prawdy naukowej wielkich szkół estetycznych XII wieku, dla których to, co wielkie, realnie zawsze pozostaje w ukryciu.

\section{Zakończenie}

W architekturze sakralnej naszych czasów obecność formalnej bariery, jaką jest lektorium, tak samo jak i jej brak, nie decyduje o tym, czy piękno cielesne jest odbierane oddzielnie od duchowego, czy łącznie z nim. Funkcjonalność architektury świątyni gotyckiej jest tym elementem, który ustala autonomię pomiędzy tymi dwoma rodzajami piękna. Coś takiego nie musi zachodzić dzisiaj.

Można przy tym powiedzieć, że po wyburzeniu lektorium jest możliwe wykorzystanie historycznego planu bazylikowego i tworzenie rzeczywistości przestrzennej nieznanej wcześniej. We współczesnej architekturze

40 B. Zevi, Apprendre à voir l'architecture, Paris 1993, s. 105. 
sakralnej wnętrze jest definiowane poprzez nawę, która jest obecnie jedna. Zależy to od jej nowej posoborowej definicji. Definiując po II Soborze Watykańskim (1962-1965) nawę nie jako obszar rozpiętości przęsłowej, ale przestrzeń przeznaczoną na zgromadzenie wiernych, podkreśla się wagę posoborowego znaczenia ogólnodostępności liturgii.

Oczywiście aby współczesny posoborowy ołtarz zbudowany w gotyckim wnętrzu przystosowanym do odnowy liturgicznej Vaticanum II został przybliżony do wspólnoty, wystarczy jego umiejscowienie na początku gotyckiego chóru pozbawionego lektorium. Taki historyczny kościół istnieje dzisiaj najczęściej jako świątynia, w której wnętrze zabytkowego prezbiterium jest przeważnie całkowicie dostępne dla wszystkich wiernych i na pewno każdy może je oglądać. Specyficznym rozwiązaniem jest umiejscowienie współczesnego ołtarza przed zachowanym lektorium, gdy zajmuje on swoje miejsce osiowo przed wejściem do gotyckiego zamkniętego chóru. Należy tutaj wymienić dwa z nielicznych zachowanych przykładów lektorium, które obecnie dobrze spełniają swoje zadanie. Są to belgijskie świątynie: bazylika Saint-Materne w Walcourt (XI-XIII wiek) i ogromna katedra Notre-Dame w Tournai (XII-XVI wiek). Spotykamy się tutaj z symboliką piękna duchowego, które jest na tyle mocne w stosunku do piękna cielesnego, że pozwolono mu zaistnieć w formie ołtarza, który aby „przybliżyć się do wspólnoty”, mówiąc językiem symbolicznym, przekroczył drzwi prowadzące do gotyckiego zamkniętego chóru od strefy nawowej i zajął swoje miejsce bezpośrednio przed obszarem przeznaczonym dla wiernych.

Układ z lektorium w historycznym wnętrzu funkcjonującym współcześnie próbuje wyrażać ducha specyficznej syntezy piękna widzialnego i niewidzialnego. Utwierdza nas ona w przekonaniu, że pomimo upływu czasu gotycka rzeczywistość estetycznego przechowywania w ukryciu tego, co jest święte, jest na tyle mocna, że daje o sobie znać nawet przy współczesnym urządzeniu gotyckiego wnętrza sakralnego. Taki powrót do zawsze aktualnego mistycznego źródła przypomina o nieprzemijającej egzystencji piękna duchowego i cielesnego, jak i o zasięgu możliwości przybliżenia tych kategorii estetycznych ku sobie. Jest to oczywiście niemożliwe bez uwzględnienia naukowej sfery średniowiecznej estetyki, która, obok mistyki świątyni gotyckiej, przy tworzeniu form sakralnych ukształtowała w pewnym sensie na zawsze predyspozycje do odnajdywania drogi w kierunku piękna duchowego. 


\section{Definition of beauty in the XII century and how it relates to architectural exposition of altars in the gothic epoch}

This article, while taking into account the mystical reality of a relic, defines gothic initiated by the abbot Surger with the construction of the first gothic basilica in Saint-Denis near Paris in the XII century, as a reality required to know the difference between individual invisible beauty and corporeal visible beauty. When the differentiation of these types of beauty shows itself, not only thanks to the unknown in Romanism mystical structure of architecture in a gothic temple, but also through the construction of the gothic altar and hiding it in a choir enclosed by a lectorium in accordance to the zone of aisles, there is a necessity for a scientific definition of beauty connected with the then contemporary stylistic changes.

This is why this article presents the main schools of aesthetic thought from the XII century, which include: the aesthetic school of Hugon of St. Victor in Paris, Cistercian school with their representative St. Bernard from Clairvaux and the aesthetic school in Chartres. With the definition of artistic types of beauty, a lot of attention is applied to the separation and coexistence of spiritual and corporeal beauty. This decides about moral beauty and the beauty of clear existence, without which there is no right knowing of the ascetic Cistercian architecture and the reality of the gothic curtain altar. Finally it is emphasized, that the importance of twelfth century aesthetics is everlasting and had introduced order to gothic architectural space, which is still found in it now, as it had been in the time of abbot Surger of Saint-Denis.

Keywords: aesthetic, beauty, altar, gothic period, gothic choir

Słowa kluczowe: estetyka, piękno, ołtarz, epoka gotycka, chór gotycki 